\begin{tabular}{|c|c|c|c|}
\hline $\begin{array}{c}\text { Case Reports in } \\
\text { Oncolois }\end{array}$ & $\begin{array}{l}\text { Case Rep Oncol 2010;3:451-457 } \\
\text { DOI: } 10.1159 / 000323003\end{array}$ & $\begin{array}{l}\text { Published online: } \\
\text { December 4, } 2010\end{array}$ & $\begin{array}{l}\text { (C) } 2010 \text { S. Karger AG, Basel } \\
\text { ISSN } 1662-6575 \\
\text { www.karger.com/cro }\end{array}$ \\
\hline
\end{tabular}

\title{
Primary Signet Ring Cell Mucinous Ovarian Carcinoma: A Case Report and Literature Review
}

\author{
Samer El-Safadi ${ }^{a} \quad$ Ulrich Stahl $^{\mathrm{b}} \quad$ Hans Rudolf Tinneberg ${ }^{\mathrm{a}}$ \\ Andreas Hackethal $^{\mathrm{a}}$ Karsten Muenstedt ${ }^{\mathrm{a}}$ \\ aDepartment of Gynaecology and Obstetrics, University Hospital Giessen \\ and Marburg $\mathrm{GmbH}$, Giessen, and ' Institute of Pathology and Cytology, \\ Wetzlar, Germany
}

\section{Key Words}

Krukenberg's tumour - Mucinous carcinoma - Ovarian cancer - Pseudomyxoma peritonei . Signet ring cell carcinoma . Pulmonary complication

\begin{abstract}
A 24-year-old female patient presented with an extremely rare primary signet cell carcinoma of the right ovary 1 year after surgery for a mucinous borderline tumour of the left ovary. Relaparotomy was carried out with right adnexectomy, appendectomy and partial omentectomy. Surgery was followed by 6 courses of paclitaxel/carboplatinum chemotherapy. After an initial response, the patient again developed increasing ascites. The patient was transferred to our hospital and a re-relaparotomy was carried out, completing the operation. After 3 courses of pegylated doxorubicin/trabectedin, the clinical course showed a positive response and a decline of the tumour marker CEA in peripheral blood. After 5 months, ascites developed in the retroperitoneum so that the chemotherapy had to be changed. In spite of a positive response with the new chemotherapy, the patient died of a very rare pulmonary complication after 1 month within 2 days.
\end{abstract}

\section{Introduction}

Krukenberg was the first to describe a signet ring cell carcinoma of the ovary [1]. Later on it was shown that these carcinomas were metastases from tumours of the gastrointestinal tract $[2,3]$. In the past few years, there were reports of 13 cases of primary ovarian stromal tumours with signet ring cells. Most of these were benign but 3 cases were primary mucinous signet ring cell carcinomas of the ovary $[4,5]$. 


\begin{tabular}{c|l|l|l}
$\begin{array}{c}\text { Case Reports in } \\
\text { Oncology }\end{array}$ & $\begin{array}{l}\text { Case Rep Oncol 2010;3:451-457 } \\
\text { DOI: 10.1159/000323003 }\end{array}$ & $\begin{array}{l}\text { Published online: } \\
\text { December 4, 2010 }\end{array}$ & $\begin{array}{l}\text { O 2010 S. Karger AG, Basel } \\
\text { ISSN 1662-6575 } \\
\text { www.karger.com/cro }\end{array}$ \\
\hline
\end{tabular}

\section{Case Report}

In August 2008, a 24-year-old nulligravida presented with a cystic mass of the left ovary measuring $25 \mathrm{~cm}$ in diameter. Laparotomy was performed with removal of the ovary. During surgery, the cyst ruptured and histology revealed a mucinous borderline tumour of the ovary. The patient received no further treatment.

One year later the patient presented again with ascites. Cytology after puncture showed malignant cells. A relaparotomy was carried out with right adnexectomy, appendectomy and partial omentectomy. The histologic examination of the right ovary showed a mucinous signet ring cell carcinoma of the ovary with peritoneal metastasis with a FIGO stage of IIIC (ig. 1). The tumour mass was widely spread in all areas of the peritoneum with a high infiltration of the bladder, colorectum and peritoneal serosa with pseudomyxoma peritonei. Because of the signet cell differentiation of the tumour, gastroscopy and CT scans were carried out which revealed no signs of gastrointestinal tumours. A complete histological examination of the appendix showed no primary carcinoma. Surgery was followed by 6 courses of paclitaxel/carboplatinum combination chemotherapy. After an initial response, the patient again developed increasing ascites.

In December 2009, the patient was transferred to our hospital. She and her family strongly decided against a standard palliative approach with pegylated doxorubicin or topotecan. It was decided to complete surgery with a hysterectomy, omentectomy, extensive reduction of tumour masses, deperitonealisation of the small pelvis as well as pelvic and paraaortal lymphonodectomy. No macroscopic residual tumour was left in the abdominal cavity. There were no signs of distant metastases. During surgery the patient received hyperthermic intraperitoneal chemotherapy with mitomycin (HIPEC).

Histological examination confirmed a signet cell adenocarcinoma of the ovary with extensive peritoneal carcinosis (fig. 2). The pTNM classification was pT3c G3 pN1 (1/20) L1 V0 R1. One lymph node in the fossa obturatoria was positive for metastasis. Immunohistochemical analyses showed no expression of the oestrogen receptor, progesterone receptor or HER2/neu receptors. Sequence analysis of EGFR showed wild type. However, the K-ras gene showed a codon 13 mutation (GGC $\rightarrow$ GAC).

The postoperative condition was complicated by a colon perforation. A lesion of the terminal ileum was sutured during emergency laparotomy. The patient recovered with a wide spectrum of antibiotics. The persistent thrombocytopenia (26,000/l) and the elevated liver enzymes (GOT $101 \mathrm{U} / \mathrm{l}, \mathrm{GPT} 111 \mathrm{U} / \mathrm{l}$, GGT $461 \mathrm{U} / \mathrm{l}$ ) were probably the result of the hyperthermic intraperitoneal chemotherapy. Gradually, all values returned to normal.

Drug sensitivity testing of the tumour cells showed sensitivity to pegylated doxorubicin, paclitaxel and capecitabine. After a thorough histological examination with comparisons to the initial mucinous borderline tumour of the left ovary, the signet cell carcinoma of the right ovary and the histology of the third laparotomy, it was decided to advise the patient to undergo 6 courses of pegylated doxorubicin in combination with trabectedin every 3 weeks. After 3 courses of treatment, the serum levels of the tumour marker CEA dropped from 966 to $207 \mathrm{ng} / \mathrm{ml}$. The serum CA 12-5 level was $43.1 \mathrm{U} / \mathrm{ml}$. After this extensive operation and with the above mentioned chemotherapy, the patient reached a high quality of life enabling her to pursue her hobbies and normal activities of life.

Five months later, the patient presented again with nausea, vomiting, loss of weight and considerable ascites in the retroperitoneum. The tumour marker CEA was beyond $500 \mathrm{ng} / \mathrm{ml}$. Cytology after CTcontrolled puncture showed malignant cells of the known ovarian cancer with low proliferation. The chemotherapy was changed to 3 courses of treosulfan every third week, bevacizumab every second week, Zoladex every fourth week and Zometa every third month. The CT scan after 1 month showed no ascites. The patient felt fine again and reached again a high quality of life, being able to pursue normal activities. After 1 month the patient died of pneumonitis, pulmonary hemorrhage and severe hemoptysis within 2 days. 


\begin{tabular}{|c|c|c|c|}
\hline $\begin{array}{l}\text { Case Reports in } \\
\text { Oncoloy }\end{array}$ & $\begin{array}{l}\text { Case Rep Oncol 2010;3:451-457 } \\
\text { DOI: } 10.1159 / 000323003\end{array}$ & $\begin{array}{l}\text { Published online: } \\
\text { December 4, } 2010\end{array}$ & $\begin{array}{l}\text { ( ) } 2010 \text { S. Karger AG, Basel } \\
\text { ISSN } 1662-6575 \\
\text { www.karger.com/cro }\end{array}$ \\
\hline
\end{tabular}

\section{Discussion}

This case report describes a very rare, poorly differentiated mucinous adenocarcinoma with signet ring cell differentiation and massive pseudomyxoma peritonei. It is not clear whether this signet cell carcinoma originated from the right ovary or whether cells from the mucinous borderline tumour, which spilled into the abdominal cavity at the first surgical intervention, caused this tumour.

\section{Signet Cell Carcinomas of the Ovary}

In general, primary signet cell carcinomas of the ovary are extremely rare. After the first description of a signet ring cell stromal tumour of the ovary [4], 15 other cases of primary signet cell tumours originating from the ovary were described; however, 13 of these cases were found to be benign according to the lack of mitotic activity and pleomorphism [4, 6-13]. Only 3 cases could be identified in the international literature on primary signet ring cell ovarian carcinoma. One of the reported tumours was a mucinous cystadenoma with a focal development of signet ring cell carcinoma. The other 2 tumours were mucinous adenofibromatous tumours with a focal signet ring cell carcinoma [5].

Signet ring cell mucinous carcinomas of the ovary are mostly metastases of primary tumours from the gastrointestinal tract, such as the stomach, the pancreas, the biliary tract or the appendix, or colorectal tumours. Primary tumours of the renal pelvis, urinary bladder, uterine cervix/corpus or mammary tumours with signet ring cell differentiation are very rare. Thus, the finding of a signet ring cell carcinoma in an ovary can no longer be classified as a metastatic tumour. On the contrary, it is necessary to distinguish the 'real' Krukenberg tumour, a signet ring cell carcinoma of the ovary, from secondary malignancies by thorough examination of the gastrointestinal organs, excluding the occurrence of other primary tumours [5]. This approach is necessary to ensure proper treatment of these tumours, including surgery and consecutive chemotherapy.

According to the literature, typical features of a primary rather than a metastatic tumour are unilateral localisation, low stage, background of adenofibroma or cystadenoma and sometimes an association with endometriosis. Moreover, there should be no evidence of metastatic tumour like bilateral tumour, deposits on the surface, nodular growth in microscopic and macroscopic examinations, extensive lymphovascular permeation, destructive stromal invasion, or tumour cells floating in mucin or extraovarian spread, although none of these would exclude this diagnosis $[5,9]$.

\section{Histopathology of Signet Ring Cell Ovarian Cancer}

Histologically, the signet ring cells are characterized by middle-sized, vacuolated tumour cells with atypical nuclei, mitotic activity and PAS-positive intracytoplasmic vacuoles. The benign stromal tumour of the ovary has different characteristics compared to mucinous ovarian cancer (table 1$)$.

In our patient, a primary signet ring cell carcinoma of the right ovary developed after a mucinous cystic borderline tumour of the left ovary had been removed. The latter presented no similarity to the now extensive peritoneal metastasic tumour. In conclusion, 
it can be assumed that a minute amount of poorly differentiated clones of malignant cells were contained in the primary borderline tumour, which was not detected in the first sampling. A primary appendix carcinoma was excluded.

Most of the specific characteristics of a 'real' Krukenberg tumour were found in the presented case, such as lymphovascular invasion, nuclear atypia, signet ring cells, mitotic activity, surface tumour deposits, poor differentiation, high CEA level, pseudomyxoma peritonei, expression of enteric markers like CK7, but lack of CK20 and CDX-2 expression which exclude colorectal or appendix tumours as the primary tumour. The description of a primary Krukenberg tumour or a second type of Krukenberg tumour has amply been discussed in the literature $[5,14]$.

Little is known about the prognosis of the primary ovarian mucinous tumour with signet ring cells. In stage IA, the prognosis seems to be favourable and similar to that of ovarian mucinous carcinoma without signet ring cells. An adverse impact on the prognosis can be expected by a massive overgrowth of signet ring cells [5].

Che et al. [15] published a follow-up of 31- to 78-year-old patients with primary microcystic ovarian carcinoma with signet ring cells. Most of them presented at FIGO stage III. Within 23 to 90 months after the initial diagnosis, 2 patients were without symptoms, 3 patients had other diseases and 4 patients died of recurrent or persistent disease.

\section{Treatment of Signet Ring Cell Carcinoma}

After an initial response to treatment the signet ring cell carcinoma showed no further response to the paclitaxel/carboplatinum standard treatment and rapidly progressed. Our treatment approach was not standard, but there was a rationale to it: hyperthermic intraperitoneal chemotherapy (HIPEC) with mitomycin after optimal cytoreduction (R0$\mathrm{R} 1$ ) has been proven to improve overall survival and disease-free survival in patients with recurrent ovarian cancer [16]. Another investigation of 52 patients with recurrent pseudomyxoma peritonei due to mucinous tumours (mucinous borderline tumour, tumour of the appendix) with a follow-up of 8.2 years showed 4 patients with no evidence of disease and the remaining cases with recurrences [17].

The choice of pegylated doxorubicin is in agreement with the most recent data from a trial consisting of 672 patients with recurrent platinum-sensitive ovarian cancer [18]. The selection of tumour therapy based on chemosensitivity assays has also been shown to be superior to those selected by physician's choice [19]. We chose to combine pegylated doxorubicin with trabectedin after it was shown that this combination is superior to pegylated doxorubicin monotherapy [20].

After 5 months the patient presented again with increased ascites in the retroperitoneum. We chose the therapeutic approach as described above (fig. 3 ), since it showed no distinct side effects and a good quality of life [21].

The patient died after 1 month of a very rare complication of bevacizumab with hemoptysis, pneumonitis and pulmonary hemorrhage within 2 days. Deaths have been reported in $1.6 \%$ of patients treated with bevacizumab. Higher risk of deep venous thrombosis and pulmonary embolism in up to $31 \%$ of the cases has been reported [22]. 


\begin{tabular}{|c|c|c|c|}
\hline $\begin{array}{l}\text { Case Reports in } \\
\text { Oncolous }\end{array}$ & \begin{tabular}{|l} 
Case Rep Oncol 2010;3:451-457 \\
DOI: $10.1159 / 000323003$
\end{tabular} & $\begin{array}{l}\text { Published online: } \\
\text { December 4, } 2010\end{array}$ & $\begin{array}{l}\text { () } 2010 \text { S. Karger AG, Basel } \\
\text { ISSN } 1662-6575 \\
\text { www.karger.com/cro }\end{array}$ \\
\hline
\end{tabular}

Our experience with the very rare primary malignant signet ring cell carcinoma of the ovary should encourage the exploration of alternative treatments of this tumour and stimulate further research. The rare complications caused by bevacizumab should be kept in mind.

Table 1. Characteristics of benign signet ring cell ovarian tumour versus malignant signet ring cell ovarian cancer $[4,8,11,12,15,23-26]$

\begin{tabular}{ll}
\hline Benign & Malignant \\
\hline Nonmucin- and nonlipid-producing & Infiltrating pattern \\
Cytoplasmic pseudoinclusions & Nests of tumour cells \\
Endomatous extracellular matrix & Positivity of mucin (PAS positive) and cytokeratin \\
No hormone effects & Malignant-looking nuclei \\
No obvious ascites & Sometimes dirty necrosis (nuclear debris) \\
Fibromatous backround & Sometimes associated with dermoid cyst or arising in \\
& dermoid cyst or part of teratoma \\
& Can be associated with low grade adenocarcinoma \\
& Poorly differentiated mucinous carcinoids of the ovary \\
(neuroendocrine marker-positive) & Can be associated with surface epithelial (serous, \\
& endometroid and mixed type) ovarian cancer \\
\hline
\end{tabular}

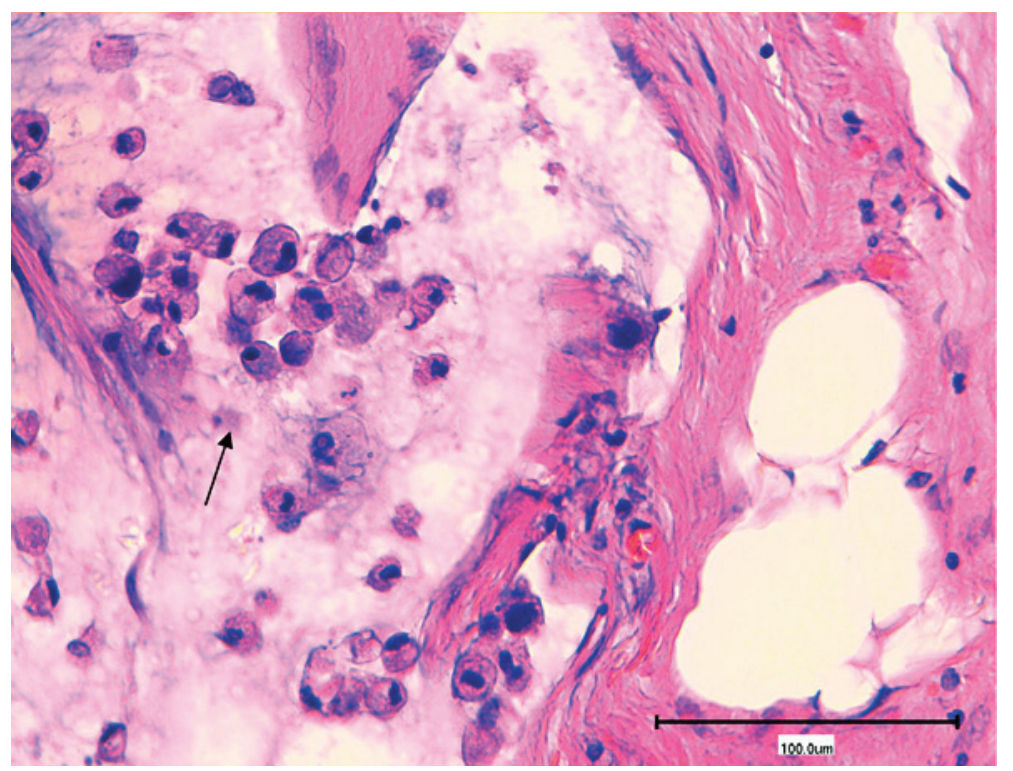

Fig. 1. Signet ring cell carcinoma of the ovary. Tumour cells are indicated by an arrow. HE stain. 


\begin{tabular}{c|l|l|l}
$\begin{array}{c}\text { Case Reports in } \\
\text { Olloloyy }\end{array}$ & $\begin{array}{l}\text { Case Rep Oncol 2010;3:451-457 } \\
\text { DOI: 10.1159/000323003 }\end{array}$ & $\begin{array}{l}\text { Published online: } \\
\text { December 4, 2010 }\end{array}$ & $\begin{array}{l}\text { ISSN 1662-6575 } \\
\text { www.karger.com/cro }\end{array}$ \\
\hline
\end{tabular}

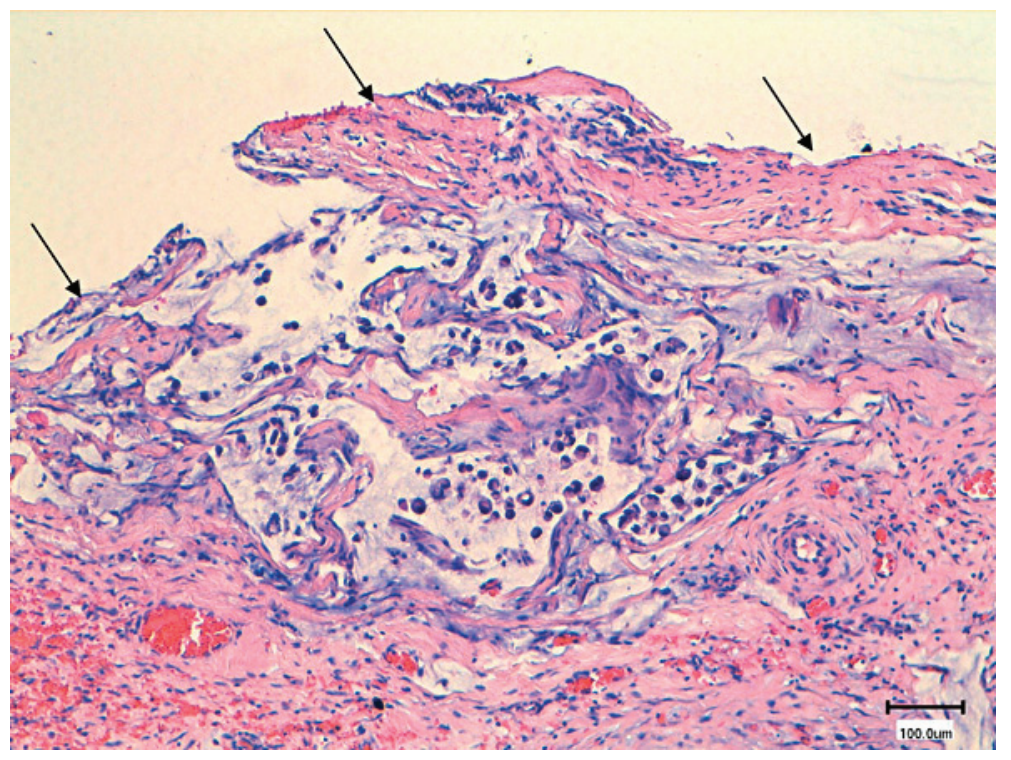

Fig. 2. Peritoneal carcinosis of a primary signet ring cell carcinoma. Peritoneal surface is indicated by arrows. HE stain.

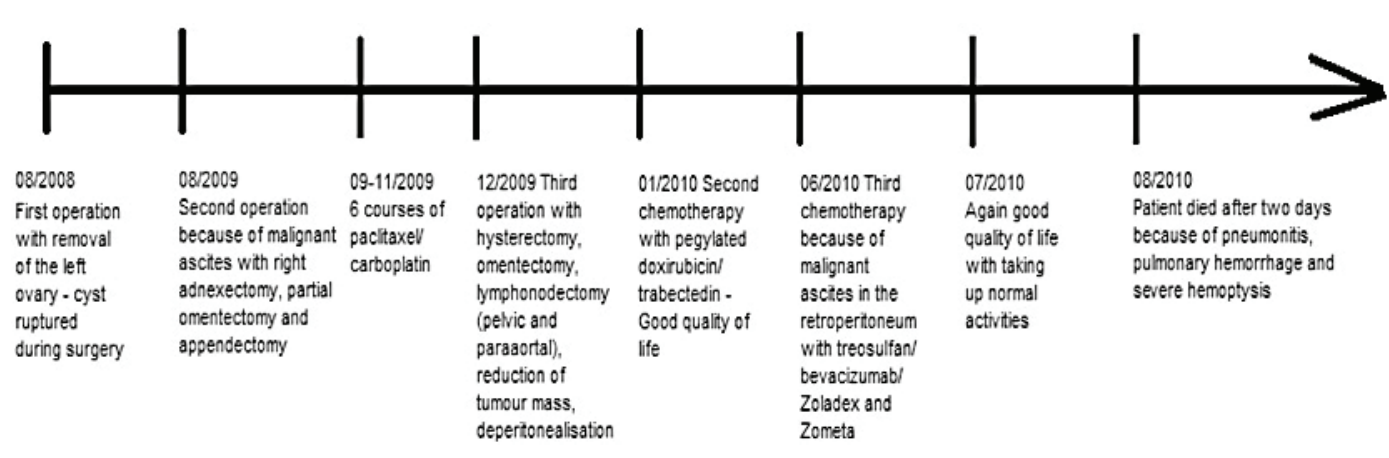

Fig. 3. Time axis of therapy procedure.

\section{References}

Krukenberg F: Über das fibrosarcoma ovarii mucocelluare (carcinomatodes). Arch Gynakol 1896;50:287-321.

Qui L, Yang T, Shan XH, Hu MB, Li Y: Metastatic factors for Krukenberg tumor: a clinical study on 102 cases. Med Oncol 2010; [Epub ahead of print].

Tan KL, Tan WS, Lim JF, Eu KW: Krukenberg tumors of colorectal origin: a dismal outcome experience of a tertiary center. Int J Colorectal Dis 2010;25:233-238.

Ramzy I: Signet-ring stromal tumor of ovary - histochemical, light and electron microscopic study. Cancer 1976;38:166-172.

McCluggage WG, Young RH: Primary ovarian mucinous tumors with signet ring cells: report of 3 cases with discussion of so-called primary Krukenberg tumor. Am J Surg Pathol 2008;32:1373-1379.

- Matsumoto M, Hayashi Y, Ohtsuki Y, Ikegami N, Toi M, Iguchi M, Hiroi M: Signet-ring stromal tumor of the ovary: an immunohistochemical and ultrastructural study with a review of the literature. Med Mol Morphol 2008;41:165-170.

-Hardisson D, Regojo RM, Marino-Enriquez A, Martinez-Garcia M: Signet-ring stromal tumor of the ovary: report of a case and review of the literature. Pathol Oncol Res 2008;14:333-336. 
Suárez A, Palacios J, Burgos E, Gamallo C: Signet-ring stromal tumor of the ovary: a histochemical, immunohistochemical and ultrastructural study. Virchows Arch A Pathol Anat Histopathol 1993;422:333-336.

-Shavo-Levy R, Kachko L, Mazor M, Piura B: Ovarian signet-ring stromal tumor: a potential diagnostic pitfall. Int J Surg Pathol 2008;16:180-184.

- Cashell AW, Jerome WG, Flores E: Signet ring stromal tumor of the ovary occurring in conjunction with Brenner tumor. Gynecol Oncol 2000;77:323-326.

Su RM, Chang KC, Chou CY: Signet-ring stromal tumor of the ovary: a case report. Int J Gynecol Cancer 2003;13:90-93.

Vang R, Bagué S, Tavassoli FA, Prat J: Signet ring stromal tumor of the ovary: clinicopathologic analysis and comparison with Krukenberg tumor. Int J Gynecol Pathol 2004;23:45-51.

- Dickersin GR, Young RH, Scully RE: Signet ring stromal and related tumors of the ovary. Ultrastruct Pathol 1995; 19:401-419.

-Joshi VV: Primary Krukenberg tumor of ovary - review of literature and case report. Cancer 1968;22:1199-1207.

-Che M, Tornos C, Deavers M, Malpica A, Gershenson D, Silva E: Ovarian mixed epithelial carcinomas with a microcystic pattern and signet ring cells. Int J Gynecol Pathol 2001;20:323-328.

Munoz-Casares FC, Rufian S, Rubio MJ, Diaz CJ, Diaz R, Casado A, Arjona A, Munoz-Villanueva MC, Muntane J: The role of hyperthermic intraoperative intraperitoneal chemotherapy (HIPEC) in the treatment of peritoneal carcinomatosis in recurrent ovarian cancer. Clin Transl Oncol 2009;11:753-759.

Friedrich M, Poleska W, Balitzer J, Salehin D: Treatment of pseudomyxoma peritonei by intraoperative and intraperitoneal chemotherapy. J Clin Oncol 2009;27(15S):e16540.

Monk BJ, Herzog T, Kaye S, et al: A randomized phase III study of trabectedin with pegylated liposomal doxorubicin (PLD) versus PLD relapsed recurrent ovarian cancer (OC). 33rd ESMO Congress Stockholm, 12-16 September 2008, Abstract LBA4.

-Cree IA, Kurbacher CM, Lamont A, Hindley AC, Love S, TCA Ovarian Cancer Trial Group: A prospective randomized controlled trial of tumour chemosensitivity assay directed chemotherapy versus physician's choice in patients with recurrent platinum-resistant ovarian cancer. Anticancer Drugs 2007;18:1093-1101.

-Herzog TJ, Vermorken JB, Pujade-Lauraine E, et al: Correlation of CA-125 and RECIST evaluation in recurrent ovarian cancer (ROC): results from a randomized phase III study of trabectedin (T) with pegylated liposomal doxorubicin (PLD) versus PLD alone. 2009 ASCLO Annual Meeting. J Clin Oncol 2009;27(suppl; abstr 5550).

-Jurado JM, Sánchez A, Pajares B, Pérez E, Alonso L, Alba E: Combined oral cyclophosphamid and bevacizumab in heavily pre-treated ovarian cancer. Clin Transl Oncol 2008;10:583-586.

Vahid B, Marik PE: Pulmonary complications of novel antineoplastic agents for solid tumors. Chest 2008;133:528 538

Lee KR, Young RH: The distinction between primary and metastatic mucinous carcinomas of the ovary: gross and histologic findings in 50 cases. Am J Surg Pathol 2003;27:281-292.

Zheng HF, Jiang BY, Shen DH: Signet ring carcinoma arising in ovarian mature teratoma: one case report. Chinese J Pathol 2005;34:610-611.

Reichert RA: Primary adenofibromatous neoplasms with mucin-containing signet-ring cells: a report of 2 cases. Int J Gynecol Pathol 2007;26:165-172.

- Baker PM, Olivia E, Young RH, Talerman A, Scully RE: Ovarian mucinous carcinoids including some with a carcinomatous component. Am J Surg Pathol 2001;25:557-568. 